\title{
INFLUENCE OF LAND USE ON MODE CHOICE BEHAVIOR OF THE CITIZENS OF KHULNA CITY
}

\author{
R. Ahasan* \& M. Mudasser \\ Urban and Rural Planning Discipline, Khulna University, Khulna, Bangladesh. \\ E-mail: rakibulahasan@gmail.com*;mehedimudasser@gmail.com \\ *Corresponding Author
}

\begin{abstract}
The information regarding travel behavior of the citizen and understanding why they are making any particular choice in their trip making is gaining vital importance in shaping the traffic management system in any city efficient and competent. Travel behavior pattern of the citizens could have both negative and positive influences on the sustainability issue of any transport system. This paper focuses on the steps of the transport demand model with two types of information- demographic information and travel data. Information regarding trip generation, the pattern of trip variation with housing types, modal choices for various purposes along with changes in income variation of citizens in Khulna City were explored using statistical tools and techniques, and trip distribution modeling was done to find out the factors affecting the trip making behavior. The findings showed that there is present a salubrious relationship between the income level of the people and their mode preferences. However, the total number of trips has influenced mostly by the income of the households where housing condition has a negative impact on the trips produced. Vehicle ownership and family size do not have that much effect on the number of trips generated. So, the consideration of both positive and negative influential variables on the travel pattern can help to outline a sustainable future transportation plan of Khulna City.
\end{abstract}

Keywords: Travel pattern; Trip-making behavior; Mode choice; Sustainable transport system

\section{INTRODUCTION}

Transportation is the science that seeks to study the problems that arise in providing transportation facilities in an urban, regional or national setting and to prepare a systematic basis for planning such facilities (Kadiyali, 2003). Khulna, the third largest city in Bangladesh, also one of the most prominent industrial domain in the country, where the vehicles, pedestrians, economic and commercial activities, official and administrative activities are increasing rapidly. However, the transportation facilities including the roads and streets, road width, management systems are not increasing, and management measures are not being upgraded as per the increasing demand. Mainly, easy-bikes, auto rickshaws, and tempo service are available as transportation modes in the city. The routes among the urban centers are usually long, and there is no bus service on those routes though it is the cheapest (Rahman \& Kabir, n.d).

The objective of this study was to understand the nature of problems that the users face in their everyday mobility throughout the city. The focus was also on the formulation of proposals for safe and efficient movement of goods and people from one place to another place. With that in mind, the whole city was divided into separate parts and areas with most transportation usage was identified. Then it was focused to collect the information on all the factors that are likely to influence the travel pattern of the citizens in the selected areas. From the initial study, 13 wards of Khulna city corporation (KCC) were found busier than the other 18 wards, and the rest of the study was focused on these 13 wards. Ward no. 18, $19,20,23,24,25,26,27,28,29,30$, and 31 of $\mathrm{KCC}$ were studied to know the travel pattern of the 
citizens in these areas. Home interview survey is performed to collect the data. Mainly household and trip data and other data related to the travel behavior of people were collected through the survey. The household information contains information such as address, size of household, age and sex structure of household, occupation, place of work, household income, vehicle ownership and so on. Travel data contains information on all journeys made during the previous 24 hour period, including the origin and destination of the journeys, the purpose of the trip, mode of travel, etc. Finally, a model which has been developed to determine the future number of trips and know the estimated future values of the independent variables. It has been already stated that this research aims to understand the travel pattern of the people of Khulna city and to identify the influences of land use on mode choice and future transport planning of this city. In this study, a mathematical relationship has been developed to synthesize the trip making pattern on the basis of observed trips and the variables related to the trip making behavior.

\section{METHODOLOGY}

This study is based on the four-step model. The first three steps have been considered out of the four steps that are trip generation, trip distribution, and modal choice. Network assignment step has just skipped for the low probability to get the actual information about the network path as the people of Khulna city uses para-transit at most often because of their default mode of transport. In the working process, activities are - select study area, determine sample size, prepare the questionnaire, conduct the field survey using prepared questionnaires, analyze the collected survey data, and create a linear model of trips produced by the surveyed households on the basis of the analysis. An unorthodox method was followed using the housing condition of the households. Total number of households in the study area were 42797 (KCC, 2011), and total population was 177588 (BBS, 2011). Total sample size was determined 630 for the whole work. Moreover, that was based on a ratio of 2:1:2 of housing conditions which were Pucca, Semi-Pucca and Katcha accordingly. The total survey work was done based on a unified questionnaire for each household selected randomly in the selected wards.

\section{RESULTS AND DISCUSSIONS}

A few analytical procedures were performed, e.g., cross tabulation, linear modeling, and multiple response analysis. These results give significant information on trip generation, the pattern of trip variation with variation in housing, modal choices for various purposes along with changes in income variation of citizens in the study area.

\section{Modes Used by the City Dwellers}

From the survey, it was found that about $33 \%$ of the people use rickshaw, and mainly the higher income people use this mode frequently because of comfort when they have to travel short distances about 2 to $5 \mathrm{~km}$ (Figure 1). Other two modes are walking and easy bike cover about half of the total. About 27\% and 25\% travel of the dwellers are covered by walking and easy bike respectively. People usually use walking mode for traveling short distances. However, many lower-income people use this mode for saving money. The other modes van, motorcycle, bus, baby taxi and car cover $2 \%$, $3 \%, 3 \%, 7 \%$ and $0.6 \%$ respectively.

\section{Housing Type and Mode}

\section{Various Modes Used by HH Members}

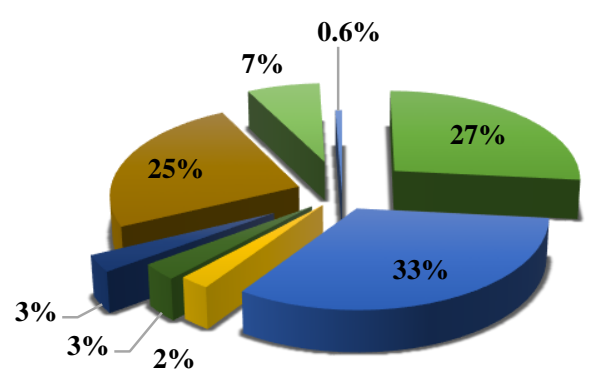

$$
\begin{aligned}
& \text { Walking } \\
& \text { Rickshaw } \\
& \text { Van } \\
& \square \text { Motorcycle } \\
& \text { Bus } \\
& \text { Easy bike } \\
& \text { Baby taxi } \\
& \text { Car }
\end{aligned}
$$

Figure 1 Various modes used by household members

The very examples can be shown from the figure above or the table below (Fig. 2) which indicates significant differences between the lower end and the higher end of the society according to the income. Moreover, with the change in income level, housing condition has also changed. Most of the people belong to the low-income group lives in Katcha or at most in semi-pucca housing. Moreover, the likes to walk before use any motorized mode for attending works. That is why people from Katcha houses like to walk near about $40 \%$ to attend workstation. 
Moreover, a portion of using easy bike is vast as most of the family members prefer using it to attend school or other social institutions and meet the basic needs (Figure 2). Although the high-income group prefers to use a rickshaw or personal car, but a portion of using the car is still low in Khulna city. Use of personal vehicles besides cars such as a motorbike, bicycle or personal car is also pretty low in the study area, and so does the use of public transport as there is no adequate public transport system in Khulna.

\section{Trip Purpose and Modes}

Use of travel modes changes with the change of purposes of any trip. It has been found that the respondents use different kinds of mode for different purposes.

Table 1: Purposes of travel and used modes

\begin{tabular}{llllllll}
\hline Modes of Travel & Work & School & Shopping & Social & Others & Back to Home & Coaching \\
\hline Walking & $28.10 \%$ & $10.40 \%$ & $7.40 \%$ & $0.80 \%$ & $8.40 \%$ & $44.90 \%$ & $0.00 \%$ \\
\hline Rickshaw & $22.60 \%$ & $18.60 \%$ & $6.70 \%$ & $4.30 \%$ & $7.30 \%$ & $40.30 \%$ & $0.20 \%$ \\
\hline Van & $34.70 \%$ & $14.70 \%$ & $1.10 \%$ & $0.00 \%$ & $4.20 \%$ & $45.30 \%$ & $0.00 \%$ \\
\hline Bicycle & $43.50 \%$ & $4.30 \%$ & $2.20 \%$ & $0.00 \%$ & $0.00 \%$ & $50.00 \%$ & $0.00 \%$ \\
\hline Motorcycle & $37.20 \%$ & $3.80 \%$ & $9.00 \%$ & $0.00 \%$ & $5.10 \%$ & $44.90 \%$ & $0.00 \%$ \\
\hline Eus & $21.40 \%$ & $17.50 \%$ & $1.90 \%$ & $1.00 \%$ & $11.70 \%$ & $44.70 \%$ & $1.90 \%$ \\
\hline Baby taxi & $34.10 \%$ & $11.40 \%$ & $8.90 \%$ & $1.90 \%$ & $6.60 \%$ & $41.60 \%$ & $0.60 \%$ \\
\hline Car & $33.30 \%$ & $0.00 \%$ & $0.00 \%$ & $0.00 \%$ & $66.70 \%$ & $0.00 \%$ & $0.00 \%$ \\
\hline
\end{tabular}

(Source: Field Survey, 2016)

Table 1 presents the purposes of travels and modes used in those cases. From the field survey, people stated that they liked to walk no matter what the purpose is. However, in the case of women or child, they use rickshaw, and easy bike for making any trip regardless of travel distance is significant. It is also considered that people use different modes at different times of the day. For example, the same man can use different modes for two trips one in a morning and one in the evening: first one for going to the office and a second one for returning to the residence. That might be for the cause of stress or tiredness of doing work all day long.

\section{Mode and Income Group}

Changes in use of mode are found among the different income groups. A person who has low income usually likes to walk whereas a person with a handsome income tends to choose the motorized mode, e.g., easy bike, personal car or others. In the study area, people who have an income range between 4000-7999 and 12000-15999 have mostly found using vehicle modes. Whereas the income range less than 2000 uses the modes lowly and in some cases, it is found as below 1\%. People with a high income (more than 20000) tends to use a variety of modes such as rickshaw, baby taxi, and private cars along with easy bike. Most modes are used by income over 4000 at least, and over 8000 is most prominent to make trips using modes beyond walking. These represent the lower income group people's inability to pay for any trip and the ability of people with higher income for any trip with modes. Figure 3 shows the significance of the collected data to portray the relationship between the income of any household 
and their use of modes. The most exciting matter that comes out from the analysis is the use of a car, or private modes of transportation is deficient in number.

Moreover, the presence of car is only in the middle-income group rather than in the higher income group people this may because of the no of trips produced by the high-income group people and their staying time in Khulna. They tend to spend a handsome time outside Khulna. So they prefer other modes rather than private vehicles.

Fig. 3: Mode used by various income group household

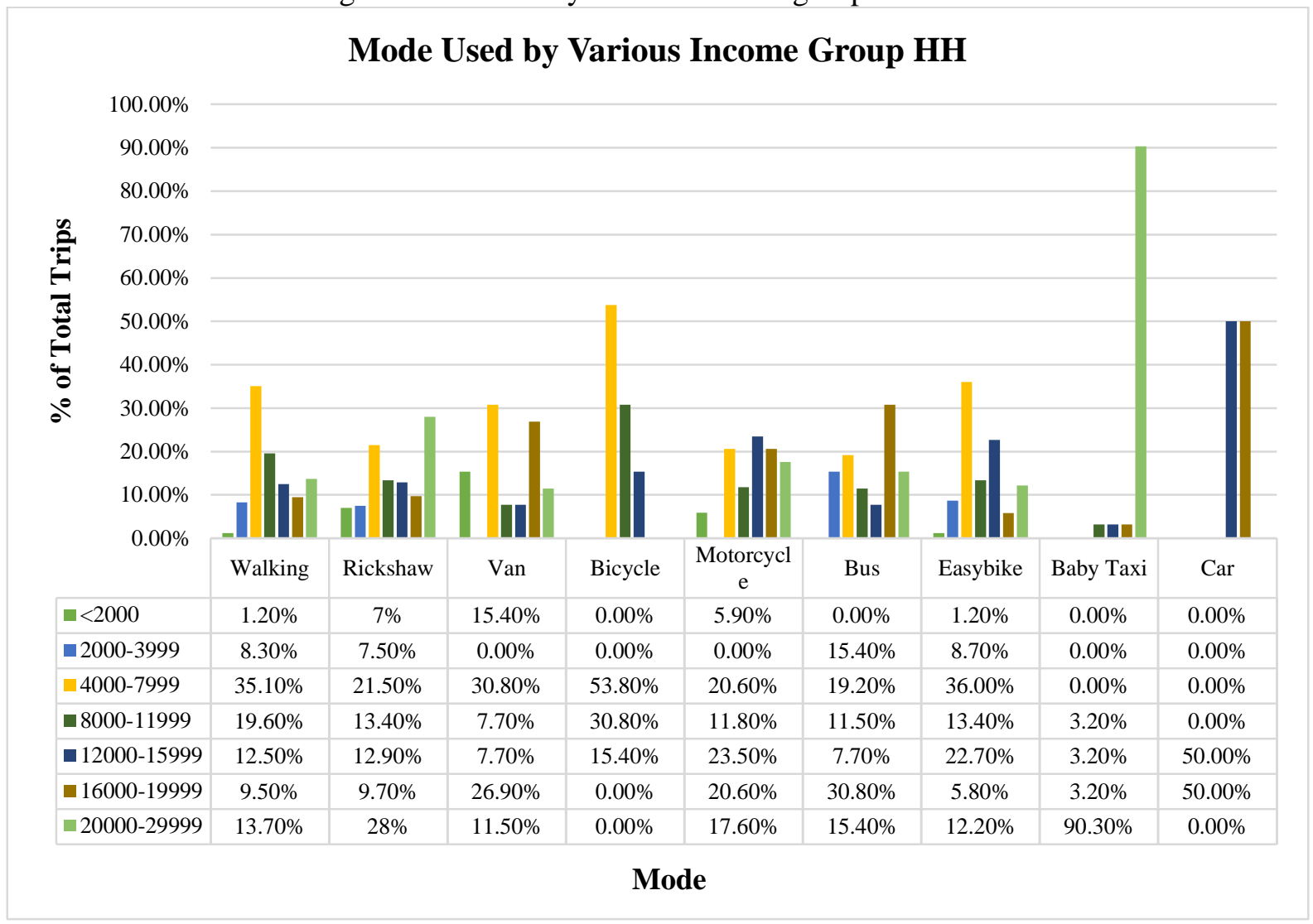

\section{Linear Models Using Various Variables}

Total number of trips are defined as a dependent variable, and total household size is defined as an independent variable. Total sample size was 630, including 252 pucca, 126 semi-pucca and 252 Katcha households. Basic statistical analysis and linear regression were performed on the collected data (table 2 , table 3 and table 4).

Table 2: Correlations between total no of trips and total $\mathrm{HH}$ size

\begin{tabular}{lll}
\hline Variables & Total trips produced by the HH members & Total family members \\
\hline $\begin{array}{l}\text { Total number of trips produced } \\
\text { by the HH members }\end{array}$ & 1.000 & .163 \\
\hline Total family members & .163 & 1.000 \\
\hline
\end{tabular}

Table 3: Description of variables

\begin{tabular}{lll}
\hline Variables & Mean & Std. Deviation \\
\hline Total number of trips produced by the HH members & 4.18 & 2.402 \\
\hline Total family members & 3.94 & 1.304 \\
\hline
\end{tabular}

The analysis shows that the correlation between two different variable total no of trips (dependent variable) and total household size (independent variable) accordingly is 0.163 and it indicates that the relationship between total numbers of trips produced by the Household members and no. of trips produced by the HH slightly correlated. From this value, it is not possible to make a reliable model or plan for transport planning. It is not representing the perfect relationship of vehicle ownership with trip making. In another word, there is no impact of vehicle ownership with produced trips in the study area. 
The mean number of trips is 4.16 , and the average number of household member is 4.02 in our study area.

Table 4: Correlations among various variables and total no of trips

\begin{tabular}{llllll}
\hline \multicolumn{1}{c}{ Variables } & $\begin{array}{l}\text { Total number of } \\
\text { trips produced by } \\
\text { the HH members }\end{array}$ & $\begin{array}{l}\text { Total } \\
\text { family } \\
\text { members }\end{array}$ & $\begin{array}{l}\text { Income } \\
\text { range }\end{array}$ & $\begin{array}{l}\text { Housing } \\
\text { condition }\end{array}$ & $\begin{array}{l}\text { Vehicle } \\
\text { ownership }\end{array}$ \\
\hline $\begin{array}{l}\text { Total number of trips produced } \\
\text { by the HH members }\end{array}$ & 1.000 & .130 & .415 & -.217 & .079 \\
\hline Total family members & .130 & 1.000 & .033 & .011 & .012 \\
\hline $\begin{array}{l}\text { Income range of the respondents } \\
\text { family }\end{array}$ & .415 & .033 & 1.000 & -.467 & .230 \\
\hline $\begin{array}{l}\text { Housing condition of the } \\
\text { respondents }\end{array}$ & -.217 & .011 & -.467 & 1.000 & -.135 \\
\hline $\begin{array}{l}\text { If any vehicle owned by the } \\
\text { respondent }\end{array}$ & .079 & .012 & .230 & -.135 & 1.000 \\
\hline
\end{tabular}

Table 5: Description of variables

\begin{tabular}{lll}
\hline Variables & Mean & Std. Deviation \\
\hline $\begin{array}{l}\text { Total number of trips produced by the HH } \\
\text { members }\end{array}$ & 4.16 & 2.449 \\
\hline Total family members & 4.02 & 1.320 \\
\hline income range of the respondent's family & 5.03 & 1.565 \\
\hline housing condition of the respondents & 2.05 & .892 \\
\hline if any vehicle owned by the respondent & 1.74 & 1.219 \\
\hline
\end{tabular}

The average number of the total trip is 4.16 , and from table 2 we get the correlation between total family members and the total number of trips which is 0.130 very close to 0 . So, there is no relationship between these two variables. Again, the relationship between the income range of the respondent's HH and the total number of trips is 0.415 which is moderately correlated, but the housing condition is negatively correlated with a total number of trips produced by the $\mathrm{HH}$ as the value is -0.217 . Moreover, vehicle ownership is not also correlated with the total number of trips, because the value is 0.079 . Besides the housing condition of the respondent negatively (-.467) affects the income range of the respondents. There is a moderate (0.443) relationship between the vehicle ownership and the number of family members and the same type of relationship found between the housing condition and the family members.

From the above data, we can build a linear regression equation involving the variables that influence the total number of variables. The equation can be shown as following using the classical linear regression equation (equation 1)-

The linear Regression equation for the study is-

Where,

$$
Y=a_{0}+a_{1} x_{1}+a_{2} x_{2}+a_{3} x_{3}+a_{4} x_{4}
$$

$\mathrm{Y}=$ dependent variable (total no of trips)

$\mathrm{x}_{1}=$ Income range

$\mathrm{x}_{2}=$ Housing condition

$\mathrm{x}_{3}=$ Vehicle Ownership

$\mathrm{x}_{4}=$ Family size

$\mathrm{a}_{0}=$ calibration constant

$\mathrm{a}_{1}=$ calibration factor affecting income $=0.415$

$\mathrm{a}_{2}=$ calibration factor affecting housing condition $=-0.217$

$\mathrm{a}_{3}=$ calibration factor affecting vehicle ownership $=0.079$

$\mathrm{a}_{4}=$ calibration factor affecting family size $=0.130$ 
So, the equation for this study using these variables will be like following-

$$
\begin{aligned}
Y_{\text {Total no.of Trips }}= & a_{0}+0.415 \text { income range }+(-0.217) \text { housing condition }+ \\
& 0.079 \text { vehicle ownership }+0.130 \text { family size }
\end{aligned}
$$

From this Eq. (2), it is easily identifiable that total number of trips is influenced mostly by the income of the households whereas housing condition has a negative impact on the trips produced. Vehicle ownership and family size do not have much impact on the no. of trips produced as they have a very low amount of calibration factor.

\begin{tabular}{|c|c|c|c|c|}
\hline Housing Type & $\begin{array}{l}\text { Total number of trips } \\
\text { produced by the HH } \\
\text { members }\end{array}$ & Pucca & Semi-Pucca & Katcha \\
\hline 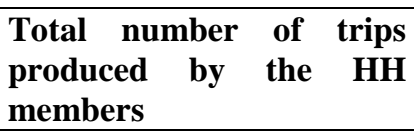 & 1.000 & .257 & -.061 & -.204 \\
\hline Pucca & .257 & 1.000 & -.401 & -.659 \\
\hline Semi-Pucca & -.061 & -.401 & 1.000 & -.425 \\
\hline Katcha & -.204 & -.659 & -.425 & 1.000 \\
\hline
\end{tabular}

Table 6: Correlations between different housing types \& Total no of trips

The objective of this analysis was to find out the relationship between various housing types and the total number of trips produced by every household. Table 6 shows the correlation between various housing types and no trips. Pucca households correlate around 0.257 which indicates that it has minimal relation or dependence with the no of trips produced. However, both semi-pucca and Katcha housing types have a negative correlation with no trips that indicates that these are not correlated.

\section{CONCLUSION}

The travel pattern of Khulna city is more or less quite same to other cities of Bangladesh. There is mixed traffic. People of higher and middle income choose the modes rickshaw and easy bike. Moreover, the van is used by both lower and middle-income people. People of all classes prefer the mode walking to cover the short distance. The people of pucca building travel frequently and use several modes. Then the katcha is in the second position and semi-pucca in third. The people use such kind of modes for various purposes. Back to home, then working are the primary purposes for traveling. The regression model stated that a total number of trips is influenced mostly by the income of the households whereas housing condition has a negative impact on the trips produced. Vehicle ownership and family size do not have that much impact on the no of trips produced as they have a meager amount of calibration factor. So, to make future transport plan for Khulna city, we have to consider the variables that positively and negatively influence the travel pattern of the people of the city otherwise, the plan will not be suitable for Khulna city.

\section{REFERENCES}

BBS. (2011, February 22). Community Report: Khulna Zilla. Retrieved January 19, 2016, from Bangladesh Bureau of Statistics: http://www.bbs.gov.bd/PageWebMenuContent.aspx?MenuKey=461 BBS. (2011, February 22). Population Census. Retrieved January 19, 2016, from Bangladesh Bureau of Statistics: http://www.bbs.gov.bd/PageReportLists.aspx?PARENTKEY=41

Kabir, M.A., and Rahman, A.F. (n.d.). Towards A Sustainable Public Transport System for Khulna City, Bangladesh. In Conference on Technology \& Sustainability in the Built Environment [Online]. Pp. 671-686. Available at: https://cap.ksu.edu.sa/sites/cap.ksu.edu.sa/files/attach/tsbe_3_e_09.pdf [Accessed 18 October 2016]

Kadiyali, L. 2013. Traffic Engineering. New Delhi: Khanna Publishers. 19p.

KCC. (2011). About Khulna City Corporation: Basic Statistics. [Online]. Available at: http://www.khulnacity.org/content/index.php?pid=30\&id=32\&page=About_KCC [Accessed 21 October 2014]. 